\title{
Mechanisms driving heme insertion into apo-sGC during its maturation in cells
}

\author{
Dennis Stuehr*, Arnab Ghosh, Anindya Sarkar, Yue Dai \\ From 6th International Conference on cGMP: Generators, Effectors and Therapeutic Implications \\ Erfurt, Germany. 28-30 June 2013
}

\section{Background}

During maturation of soluble guanylyl cyclase (sGC), heme insertion into the beta subunit is essential because it enables sGC to recognize nitric oxide (NO) and transduce its biological effects. We used a mammalian cell culture approach and followed heme insertion into both transiently- and endogenously-expressed apo-sGC beta. Although sGC is often associated with heat shock protein 90 (hsp90) in cells, the implications are unclear. Experiments that used pharmacological hsp90 inhibitors, an ATP-ase inactive hsp90 mutant, and heme-dependent or heme-independent sGC activators revealed that heme insertion into apo-sGC requires hsp90 [1].

\section{Results}

Our findings suggest a model where apo-sGC beta may directly complex with hsp90, which then drives heme insertion into apo-sGC beta through its inherent ATPase activity. In follow-up studies we are using purified proteins and domains and fluorescence and hydrogen-deuterium exchange methods to characterize the apo-sGC interaction with hsp90 at the molecular level. Results indicate that apo-sGC beta binds to the hsp90 middle domain, and the binding interaction involves structural regions within the heme and PAS domains of sGC.

\section{Conclusion}

Together, our work is shedding light on the sGC maturation process, and is revealing new ways that sGC activity could be impacted or controlled in cells.
Published: 29 August 2013

\section{Reference}

1. Ghosh A, Stuehr DJ: Soluble guanylyl cyclase requires heat shock protein 90 for heme insertion during maturation of the NO-active enzyme. Proc Natl Acad Sci U S A 2012, 109:12998-13003.

doi:10.1186/2050-6511-14-S1-018

Cite this article as: Stuehr et al:: Mechanisms driving heme insertion into apo-sGC during its maturation in cells. BMC Pharmacology and Toxicology 2013 14(Suppl 1):018.
* Correspondence: stuehrd@ccf.org

Department of Pathobiology, Lerner Research Institute, Cleveland Clinic, Cleveland Ohio, USA
Submit your next manuscript to BioMed Central and take full advantage of:

- Convenient online submission

- Thorough peer review

- No space constraints or color figure charges

- Immediate publication on acceptance

- Inclusion in PubMed, CAS, Scopus and Google Scholar

- Research which is freely available for redistribution
C Biomed Central 